\title{
BERJILBAB DI “KAMPUNG INGGRIS”: ANTARA KEPATUHAN DAN RESISTENSI
}

\author{
Rose Kusumaning R dan Syifa Hamama \\ Institut Agama Islam Nahdlatul Ulama (IAINU) Kebumen \\ e-mail:rsratri@gmail.com
}

\begin{abstract}
Abstrak
Pakaian telah meninggalkan fungsi alaminya sebagai pelindung tubuh. Hal ini karena pakaian memiliki makna yang kompleks. Siapa anda dan dimana anda berasal dari dapat diketahui dari cara mengenakan pakaian tertentu. Aturan menggunakan pakaian dalam lokasi Kursus Bahasa Inggris, Basic English Course (BEC) adalah fenomena biasa. Hal ini karena Kursus Bahasa Inggris yang nonformal biasanya membiarkan siswa mereka untuk mengenakan pakaian favorit mereka. Aturan pakaian yang tersirat di Kursus Bahasa Inggris adalah kewajiban untuk mengenakan jilbab bagi perempuan muslim. Aturan menggunakan jilbab menjadi masalah dan menarik karena BEC tidak berafiliasi ke organisasi masyarakat berbasis agama. Kursus ini dimiliki dan dikelola oleh individu. Akhirnya, pemahaman terhadap penggunaan jilbab bukan hanya perintah agama. Hal ini karena makna pluralitas pakaian, ada kemungkinan motivasi perbedaan dan interpretasi atau antara tujuan dan praktik berjilbab.
\end{abstract}

Kata Kunci: Jilbab, Wacana, Tubuh.

\section{A. Pendahuluan}

"Kampung Inggris" berada di wilayah Desa Tulungrejo, termasuk dalam daerah administratif Kecamatan Pare, Kabupaten Kediri, Jawa Timur. Penamaan "Kampung Inggris" bukan merujuk pada komunitas orang Inggris, melainkan mengacu pada keberadaan lembaga-lembaga kursus bahasa Inggris 
yang berjumlah lebih dari seratus lembaga. Para peserta yang mengikuti kursus berasal dari berbagai daerah berskala nasional. Perkembangan "Kampung Inggris" berawal dari lembaga kursus Basic English Course (BEC) yang didirikan oleh M. Kalend Osen pada tahun 1976.

Selain sebagai pusat belajar bahasa Inggris, karakteristik khas lain di "Kampung Inggris" adalah aturan berpakaian, yakni berjilbab bagi peserta perempuan beragama Islam pada beberapa lembaga kursus. Lembaga yang menerapkan aturan tersebut adalah Basic English Course (BEC), Happy English Course (HEC) I dan II, serta Effective English Conversation Course (EECC). Aturan tersebut muncul pertama kali di lembaga BEC yang ditetapkan oleh Kalend Osen. Sementara tiga lembaga lain merupakan cabang dari BEC yang menerapkan tata aturan dan sistem pembelajaran yang sama.

Rincian aturan dalam berjilbab bagi para perempuan Muslim adalah tidak diperbolehkan mengenakan celana jeans ketat, sekalipun bercelana, model yang dipakai berbahan kain dan longgar. ${ }^{1}$ Aturan ini tidak hanya diterapkan kepada para peserta perempuan, tetapi juga para pengajar yang bersifat mengikat. Para pengajar perempuan diwajibkan berbusana jilbab dipadu bawahan rok atau celana kain longgar dengan model baju atasan panjang sampai menutup pantat, bersepatu, dan berkaos kaki. Sanksi terhadap pelanggaran ditindak tegas dengan hukuman paling berat adalah dikeluarkan.

Dalam sepanjang penyelenggaraan, aturan ini mapan diterapkan. Artinya, para perempuan yang dalam keseharian tidak berjilbab mau mengenakan jilbab agar dapat belajar bahasa Inggris di BEC. Hal tersebut memancing problematika yang dilatarbelakangi setidaknya tiga hal. Pertama, BEC adalah lembaga nonformal yang tidak diwajibkan untuk diikuti oleh seseorang sehingga pilihannya lebih kepada mana suka. Kedua, BEC merupakan satu lembaga dari sekian banyak lembaga kursus yang mencapai jumlah ratusan di “Kampung Inggris”.Ketiga, BEC tidak berafiliasi kepada organisasi masyarakat berbasis keagamaan tertentu.

Terkait dengan aturan wajib berjilbab, disadari bahwa berpakaian bukan praktik sosial yang sederhana. Pakaiandapat menjadi media

$1 \quad$ Kalend tidak mengizinkan mode jilbab yang menutupi seluruh tubuh yang hanya menyisakan lubang untuk bagian mata atau bercadar. Mode lain, yakni selendang yang disampirkan di kepala dengan tetap menampakkan bagian leher juga tidak diperbolehkan. 
komunikasi artifaktual yang menyimpan makna tertentu. Cara berpakaian bukan merupakan sesuatu yang alamiah, melainkan dipelajari, diadopsi, dinegosiasikan, dikembangkan, disesuaikan, dan digunakan untuk mencapai sebuah tujuan. Konvensi nilai, norma, dan kaidah sosial akanmengarahkan atau menyarankan cara-cara berpakaian tertentu dalam kontekstertentu dan tidak memungkinkan pilihan lain². Maka, dalam perspektif tersebut, pakaian menjadi sistem penanda yang direproduksi oleh tatanan sosial yang mengonstruksi identitas si pemakai. Reproduksi dan konstruksi lebih lanjut akan memuat aspek kekuasaan dan ideologi yang di dalamnya mengandung unsur-unsur politis, seperti nilai, keyakinan, ide-ide, dan pandangan sebuah kelompok.

Meskipun demikian, individu memiliki potensi kemampuan untukmengamati, membentuk motif, melakukan penalaran, dan memiliki kesadaran atastindakan yang dilakukan. Artinya, meskipun terlingkupi oleh sejumlah kaidah dankonvensi tertentu, individu tidak sekadar menjadi subjek-subjek pasif yang digerakkanoleh kekuatan sosial. Individu tetap memiliki ruang kemerdekaan dalam mengambil keputusan atas tindakan yang dilakukan.

Pada posisi ini, pakaian berkait-kelindan secara internal dan eksternaldalam diri individu. Artinya, ketika seseorang berpakaian, ia akan memilih jenispakaian yang sesuai dengan kepribadiannya, tetapi sekaligus pilihannyadipengaruhi oleh formasi sosial budaya tempat ia berada. Implikasinya, pakaian berperan ganda, yakni sebagai kulit sosial yang menunjukkan afiliasibudaya serta cara individu menampilkan diri. Peran tersebut mengandung pergulatan antara bagaimana diri dipengaruhi dan memengaruhi cara berpakaian serta bagaimana ruang sosial dipengaruhi dan memengaruhi tampilan berpakaian. ${ }^{3}$

Berpijak pada kompleksitas cara berpakaian, aturan berjilbab di lembagakursus menjadi sesuatu yang tidak lagi sederhana. Pakaian adalah mediumkomunikasi artifaktual, sementara berjilbab berhubungan dengan aspekreligiusitas. Dalam kerangka keagamaan, jilbab merupakan model

2 Henk Schulte Nordholt (ed.), Outward Appearances: Tren, Identitas, Kepentingan,Terj. M. Imam Aziz,(Yogyakarta: LKiS, 2005), hlm. 2.

3 Malcolm Barnad, Fashion sebagai Komunikasi, Terj. Idi Subandi Ibrahim, (Yogyakarta: Jalasutra, 2011). 
pakaianperempuan Islam berlatar belakang pada kebudayaan Timur Tengah, yangditerima oleh umat Muslim sebagai salah satu pengejawantahan dari ketaatanberagama.

Di Indonesia, sejarah dan keberterimaan jilbab telah berlangsung sejak masa penjajahan kolonial. Namun, momentum perkembangan pemakaian jilbab secara meluas berkaitan dengan Revolusi Iran pada 1979' Walaupun demikian, pada rentang akhir tahun 1970-an berlanjut pada tahun 1980an, jilbab masih menjadi busana kaum minoritas. Meskipun jilbab menjadi simbol gerakan kelas menengah dan kalangan terdidik, perempuan berjilbab tidak lebih banyak mendapatkan keuntungan dalam masyarakat. Bahkan, perempuan yang memutuskan berjilbab berisiko dikritik dan digosip dengan pelabelan fanatik, berlagak suci, atau selalu salah jalan ${ }^{5}$. Ketidakpopuleran jilbab pada masa ini di antaranya disebabkan oleh perlakukan Pemerintah Orde Baru yang menganggap jilbab sebagai bagian dari fundamentalisme Islam. ${ }^{6}$

Karakter subversif jilbab sebagaimana pada era 1980-an mulai memudar pada tahun 1990-an. Bahkan jilbab menjadi semakin populer menjelang akhir pemerintahan masa Orde Baru. Pada tahun-tahun ini, ketika semakin tidak mendapatkan dukungan dari rakyat, Rezim Orde Baru berupaya mendekati komunitas Islam. Salah satu cara menarik simpati masyarakat Islam ialah dengan mendukung pemakaian jilbab. Perkembangan selanjutnya, jilbab menjadi semakin populer ketika tampil di media massa dan mendapatkan dukungan dari kapital menjadi gaya hidup sebagai fashion.

Meskipun dalam perspektif historis-antropologis jilbab tidak hanya berhubungan dengan ajaran agama tertentu, pada masa kini jilbab identik

$4 \quad$ Revolusi Iran terjadi ketika Imam Khomeini berhasil mengalahkan rezim Reza Pahlevi. Keberhasilan Khomeini bukan hanya secara de facto menggulingkan pemerintahan Pahlevi, melainkan pula menjadi lambang kemenangan Islam atas Barat dan para sekutunya. Eforia kemenangan Khomeini meluas dari Iran sampai ke tempat-tempat yang terdapat komunitas Muslim termasuk Indonesia. Foto Khomeini dan black veil menjadi tren sebagai lambang dari ekspresi penolakan terhadap pengaruh Barat.

5 Suzzane Brenner, "Reconstructing Self and Society: Javanese Muslim Women and The Veil," Dalam American Ethnologist, Vol. 23, No. 4 (November 1996), hlm. 675.

6 Banyak penelitian dilakukan menyoroti perkembangan jilbab di Indonesia pada masa ini, di antaranya Suzzane Brenner dalam "Reconstructuring Self and Society: Javanese Muslim Women and "The Veil"”; Adelen Matthewman dalam "Jilbabisasi Mengapa Muslimah Jawa Berjilbab". 
dengan Islam ${ }^{7}$. Eksistensi jilbab bahkan menjadi bagian dari simbol-simbol keislaman. Simbolisasi ini terepresentasi dalam berbagai modus, salah satunya melalui formalisasi pada peraturan ketatanegaraan, baik melarang maupun mengharuskan dalam skala regional atau pemerintah pusat. ${ }^{8}$

Pemahaman religius dalam ajaran-ajaran agama tidak hanya berhubungan dengan fatwa para ulama dan pembelajaran kitab suci, tetapi mencakup pula simbolisasi konsep atau benda-benda tertentu. Simbolisasi salah satunya digunakan untuk mengintrepretasikan ajaran agama itu sendiri. Simbolisasi juga mempertegas fungsi jilbab sebagai media komunikasi. Berjilbab akhirnya memproduksi, mengungkapkan, dan mempertukarkan makna identitas seseorang.

$7 \quad$ Jilbab dalam bahasa Inggris dikenal dengan kata veil. Kata ini dipakai untuk merujuk pada penutup tradisional kepala, wajah, atau tubuh wanita Timur Tengah dan Asia Selatan. Kata veil berasal dari bahasa Latin vêla, bentuk jamak dari velum yang berarti "penutup" dalam pengertian "menutupi" atau "menyembunyikan atau menyamarkan" Makna kata veil meliputi dimensi material, ruang, komunikasi, dan religius yang lebih luas. El Guindi menjelaskan secara terperinci kata veil dapat merujuk pada arti (1) kain panjang yang dikenakan wanita untuk menutupi kepala, bahu, dan seringkali muka; (2) rajutan panjang yang ditempelkan pada topi atau tutup kepala wanita, yang dikenakan untuk memperindah atau melindungi wajah dan kepala; (3) a.bagian penutup biarawati yang melingkari wajah sampai ke bawah menutupi bahu, b. Kehidupan atau sumpah biarawati; dan (4) secarik tekstil tipis yang digantung guna memisahkan atau menyembunyikan sesuatu yang ada di sebaliknya; sebuah korden. Pada referensi lain makna kata "veil dan veiling" diatur dengan menggunakan beberapa huruf besar, antara lain: A. hubungan emosional antarpribadi: (1) tidak kawin; (2) menutupi sesuatu; (3) bayang-bayang sesuatu; B. jenis-jenis komunikasi: (1) menyembunyikan sesuatu; (2) penyamaran, samar, disamarkan; (3) penipuan, kepura-puraan; C. benda-benda organik (material): (1) layar; (2) ketidaktampakan; (3) kesuraman; (4) kegelapan; (5) pandangan kabur; dan D. berpakaian dalam "ruang dan dimensi tertentu". Merupakan sesuatu yang menarik bahwa "jilbab sebagai pakaian" disebutkan terakhir dalam daftar makna di atas. Dalam sebuah pengelompokan lain, yaitu Religi: Resmi terdapat makna "barang-barang keagamaan", "penutup", "pemingitan", "hal-hal yang berhubungan dengan biarawan/biarawati", "sesuatu yang gaib”. FadwaEl Guidi, Veil, Modesty, Privacy, and Resistance, (New York: Berg, 1999), hlm. 6. Lihat Nasrudin Umar, "Antropologi Jilbab", dalam Ulumul Quran No.5 Vol. VI Tahun 1996.

8 Pandangan jilbab sebagai simbol Islam salah satunya terepresentasi dari kebijakan Pemerintah Prancis yang melarang penggunaan jilbab di sekolah-sekolah Prancis. Peraturan ini ditetapkan pada 10 Februari 2004 atas dasar keinginan untuk menjaga pluralitas dan sekularitas. Sementara di Negara Indonesia, beberapa Perda daerah mengatur penggunaan busana muslimah (jilbab), antara lain surat edaran Bupati Kabupaten Banjarmasin No. 065.2/00023/ORG, tanggal 12 Januari 2004, tentang pemakaian jilbab bagi PNS Perempuan di Lingkungan Pemerintah Kabupaten Banjarmasin; Perda Kabupaten Maros No. 16/2005 tentang tata cara berpakaian Muslim dan Muslimah; instruksi Bupati Sukabumi No. 4 tahun 2004 tentang Pemakaian Busana Muslim bagi Siswa dan Mahasiswa di Kabupaten Sukabumi. Sementara daerah lain yang menerapkan peraturan tentang busana muslim/muslimah atau pakaian dinas (pakaian menutup aurat) antara lain Solok (Perda No. 6/2002); Bulukamba (Perda No. 5/2003); Maros (Perda No. 16/2005); Enrekang (Perda No. 6/2005); Pasaman (Perda No. 22/2003); Sawahlunto (Perda No. 2/2003), dan lain-lain. Moh. Fauzi, Formalisasi Syariat Islam di Indonesia, (Semarang: Walisongo Press, 2008), hlm. 27 
Dengan demikian, berjilbab membangkitkan beragam kemungkinan bergantung pada konteks mana diterapkan. Dalam konteks aturan berjilbab di lembaga BEC, makna jilbab tidak selesai ketika dirujuk pada common sense bahwa berjilbab mengacu pada perintah ajaran agama. Hal ini karena tidak menutup kemungkinan terdapat perbedaan antara motivasi dengan penafsiran, antara tujuan dan praktik pelaksanaan. Problematikanya ialah mengapa para peserta mau patuh berjilbab meskipun pada kenyataannya para perempuan yang belajar di BEC tidak seluruhnya dalam keseharian menggunakan jilbab?

Untuk mengkaji aturan berjilbab, ada dua konsep teori yang digunakan, yakni habitus dari Pierre Bourdeau dan individualisasi dari Michel Foucault. Konsep habitus diarahkan untuk mengkaji mengapa aturan berjilbab diterapkan dan bagaimana habitus pemilik kursus yang melatarbelakangi dan mendorong munculnya tindakan menerapkan aturan berjilbab. Setiap tindakan yang dilakukan oleh seseorang memiliki dasar pijakan kerangka yang memungkinkan ia memutuskan dan melakukan sebuah praktik bertindak. Kerangka pijakan, latar belakang, dan kecenderungan berbuat secara sederhana dapat dikatakan sebagai habitus. Tindakan menetapkan aturan berjilbab dan tindakan mau berjilbab untuk mematuhi peraturan akan dapat dipahami ketika habitus seseorang diuraikan.

Selanjutnya, melalui konsep individualisasi digunakan untuk mendedah relasi kekuasaan yang mengatur para peserta kursus sehingga mereka mau patuh dan disiplin menjalankan aturan berjilbab. Maka, penelitian ini bertitik tolak pada dua sisi dalam menginterpretasikan aturan berjilbab. Pada satu sisi dari sudut pandang pemilik kursus, sedangkan di sisi yang berseberangan dari para peserta.

\section{B. Imajinasi Tentang Jilbab Pada Aturan Berjilbab}

Aturan berpakaian lahir dari landasan pandangan dan pengetahuan tertentu. Pengetahuan dapat diartikan sebagai pemikiran, gagasan, konsep, pemahaman, pengertian, tentang kehidupan manusia di dunia. Landasan pengetahuan dan pandangan tentang aturan berjilbab ini yang penulis katakan sebagai imajinasi tentang jilbab. Imajinasi tersebut menjadi bagian dan bersumber dari habitus Kalend. Pada sisi lain, aturan adalah seperangkat 
norma yang mendikte tindakan mana yang diizinkan dan dilarang. Aturan melibatkan dua belah pihak, yakni subjek pembuat aturan dan subjek yang dikenai aturan. Kepada pihak yang dikenai aturan, kebebasan yang dimiliki akan terbatas karena harus melakukan penyesuaian.

Pada awalnya, peristiwa pengusiran siswi berjilbab di SMA 4 Surabaya merupakan pemicu lahirnya aturan berjilbab di BEC. Peristiwa tersebut merupakan salah satu kasus rangkaian dari kasus-kasus pelarangan berjilbab di sekolah pada sepanjang tahun 1980-an, yang dikenal dengan nama "kasus jilbab”. Pada masa tersebut, jilbab mendapatkan stigma yang diidentikkan sebagai tradisional, kampungan, militan, dan beragam citra buruk yang menempatkan jilbab sebagai sesuatu yang inferior dan pantas dicurigai. Pada beragam kasus pelarangan yang terjadi, perjuangan dan proses penyelesaian kasus pada akhirnya memenangkan para perempuan untuk mendapatkan haknya dalam berjilbab. Dengan demikian, dilihat dari sejarahnya, aturan berjilbab lahir dari tindakan resistensi yang dilakukan oleh Kalend atas peristiwa pelarangan jilbab pada awal masa tahun 1980-an.

Individu dalam melakukan tindakan tidak hanya dipandu berdasarkan pertimbangan rasional, tetapi juga dipengaruhi pengalaman masa lalu. Dalam penjelasan Bourdieu, habitus sangat kompleks. Habitus dapat dipahami sebagai struktur yang terstrukturasi (structured structures) dan struktur yang menstruktur (structuring structures). ${ }^{9}$ Habitus subjektif yang dimiliki dibentuk untuk melakukan penyesuaian individu dengan lingkungan sosial dan secara bersamaan penyesuaian lingkungan sosial dengan individu.

Pada riwayat hidupnya, Kalend pernah belajar di Pondok Modern Darussalam, Gontor, Ponorogo. Setelah itu, berguru kepada Kiai Ahmad Yazid, pengasuh pondok Pesantren Darul Hikmah, Pare, Kediri. Di Pare, Kalend menetap, kemudian mendirikan lembaga kursus bahasa Inggris yang diberi nama Basic English Course. Bertolak dari pengalaman belajar di Pesantren Gontor dan kepada Kiai Yazid memengaruhi cara berpikir dan bertindak yang menjadi habitus subjektif Kalend.

Kalend adalah figur sentral dalam mendirikan, mengembangkan, dan memimpin BEC. Peraturan dan sistem pembelajaran yang diterapkan

9 Pierre Bourdieu, Outline of a Theory of Practice,(New York: Cambridge University Press, 1995). 
merupakan hasil pemikiran dan keputusannya. Namun demikian, perkembangan dan kemajuan BEC ditopang oleh modal sosial yang dimiliki Kalend. Sosok Kiai Ahmad Yazid adalah kiai yang menguasai sembilan bahasa asing. Sebelum BEC didirikan, kemampuan bahasa asing Kiai Yazid menjadi daya tarik orang untuk belajar kepadanya di Pare. Selain itu, Kiai Yazid merupakan narasumber dan teman diskusi Clifford Geertz, antropolog dari Amerika Serikat.

Sementara itu, dalam pandangan masyarakat awam, "Kampung Inggris" dikenal sebagai daerah yang menggunakan bahasa Inggris sebagai bahasa pengantar sehari-hari dan sering dikunjungi oleh orang asing. Sejumlah orang asing yang datang ke Pare bukan tidak mungkin berkaitan dengan penelitian yang dilakukan oleh Clifford Geertz. Daerah Mojokuto sebagaimana disebutkan dalam penelitian Geertz adalah wilayah Pare. Dari dua hal ini kepopuleran Kiai Yazid dan aktivitas penelitian Geertz-menjadi faktor yang secara langsung maupun tidak langsung memengaruhi perkembangan BEC dan "Kampung Inggris" dalam cakupan lebih luas sebagai ikon tempat belajar bahasa Inggris.

Karakteristik dalam sistem belajar mengajar di BEC ialah kedisiplinan termasuk tata tertib berpakaian. Tujuan dari disiplin adalah mengatur. Tujuan ini pula yang ingin dicapai Kalend ketika menciptakan tata tertib berpenampilan. Agar mudah dalam mengatur, dibuat penyederhanaan, maka para perempuan diatur dan disederhanakan dalam satu tipe berpakaian, yakni berjilbab. Dari sini, jilbab dipandang sebagai penanda kesiapan seorang Muslimah yang bisa diatur. Maka dari itu, berawal sebagai penanda kesiapan, dalam pandangan Kalend, fungsi jilbab berkembang menjadi tanda yang menunjukkan kondisi jiwa. Perempuan yang tidak mau mengenakan jilbab dikatakan "penyakit" yang menunjukkan individu tersebut tidak dapat diatur. Padahal menurut Kalend, syarat dalam menuntut ilmu agar dapat belajar dengan baik adalah kesiapan hati untuk mampu dan mau diatur.

Kesederhanaan dan fungsi pengaturan sebagaimana diungkapkan Kalend mengacu pada konteks ajaran Islam. Dalam Islam, akidah, ibadah, akhlak, dan masyarakat terikat menjadi satu. Akidah adalah landasan pertama dalam beragama. Jika ajaran ini dikaitkan dengan jilbab dan aturan berjilbab, 
terdapat alur berpikir sebagai berikut. Memakai jilbab bagi perempuan adalah perintah agama berkenaan dengan keharusan menutup aurat sehingga bernilai sebagai ibadah. Ibadah merupakan metode untuk mendidik akhlak dan moralitas individu. Jika seorang Muslimah mau dan taat menjalankan perintah menutup aurat, ini menjadi salah satu bukti kebenaran iman dan tanda kebenaran seorang Muslim. Inilah penjabaran dari pemikiran Kalend bahwa jilbab menjadi cara untuk melihat kondisi jiwa, membentuk karakter, dan mengetahui sikap seseorang.

Dari pemikiran Kalend dapat ditarik pemahaman bahwa titik temu antara aturan berjilbab dengan penyelenggaraan pendidikan bahasa Inggris adalah belajar bahasa Inggris dipandang sebagai aktivitas keduniawian yang harus ditopang dan dilandasi oleh kebenaran dalam beragama (menjalankan perintah agama). Lalu, cara untuk konsisten terhadap tujuan yang ingin diraih, yakni dibuat pola pendidikan yang menekankan kedisiplinan ketat.

Dalam hal ini, Islam menjadi unsur pembentuk skema klasifikasi generatif dan disposisi yang menghasilkan tindakan menerapkan aturan berjilbab. Setidaknya terdapat lima fungsi aturan berjilbab, yakni a) penyaring; b) pendisiplinan; c) penyeragaman; d) pembentukan karakter; e) identifikasi. Jilbab berfungsi sebagai penyaring karena dengan adanya aturan ini hanya perempuan-perempuan berjilbab dan mau berjilbab yang mendaftar danbertahan menjadi siswa BEC. Perempuan yang tidak mau berjilbab akan tereliminasi oleh aturan. Jilbab menjadi sarana untuk mendisiplinkan dan menyeragamkan para peserta. Disiplin dan seragam berfungsi mengontrol dan mengendalikan peserta untuk mengikuti aturan yang ditetapkan. Ketika peserta mampu diseragamkan, kontrol atas mereka menjadi lebih mudah. Peserta yang tidak mau diseragamkan akan diidentifikasi tidak disiplin sehingga memeroleh sanksi pelanggaran.

Terakhir, fungsi berjilbab sebagai pembentukan karakter merupakan fungsi berjilbab sebagaimana diimajinasikan oleh pemilik kursus atau pembuat aturan. Kalend berpandangan bahwa praktik berjilbab akan mampu mengidentifikasi karakter seseorang apakah baik atau tidak baik. Dalam fungsi ini, berjilbab menjadi tolok ukur menilai karakter individu sekaligus tersirat pandangan bahwa praktik berjilbab dihubungkan dengan aspek moral. 


\section{PERGULATAN MAKNA JILBAB: PENGALAMAN EMPAT PE- REMPUAN}

Empat subjek penelitian ialah Rifka, Rini, Nabila, dan Titin. Keempat subjek tersebut merupakan hasil dari pemilihan dan pemilahan yang dianggap mampu mewakili data.

\section{Pengalaman Rifka}

Sebelum mendaftar, Rifka telah mengetahui profil dan sistem pembelajaran yang diterapkan oleh BEC, termasuk aturan berjilbab. Menurutnya, ia tidak mempermasalahkan aturan berjilbab karena telah berjilbab ketika bersekolah di SMP dan SMA walaupun sebenarnya tidak setuju dengan aturan tersebut. Alasan ketidaksetujuan karena faktor cuaca Pare yang panas sehingga ketika berjilbab menjadi semakin gerah.

Hal yang menjadikan Rifka tidak setuju, selain karena faktor cuaca adalah berjilbab dianggap sebagai pilihan pribadi. Rifka memahami tentang kewajiban menutup aurat bagi Muslim, tetapi menurutnya tidak diperbolehkan adanya paksaan. Berjilbab harus didasari keinginan dari hati pribadi bukan karena tekanan atau paksaan dari pihak luar. Selama belajar di BEC, ia mengatakan "kerelaan" berjilbab demi kepentingan ingin belajar.

Perempuan berjilbab menurut Rifka setidaknya memiliki dua syarat, yakni aspek teologis dan psikologis. Dalam aspek teologis, jilbab merupakan perintah agama karena tubuh perempuan adalah aurat yang harus ditutup. Rifka mensyaratkan jika perempuan telah berjilbab, seharusnya telah memiliki iman yang teguh, kebaikan hati, dan perilaku baik. Berjilbab akan percuma jika masih tetap melanggar perintah agama yang lain.

Selain aspek teologis, syarat berikutnya adalah aspek psikologis. Berjilbab sebagai pilihan individu harus berpijak dari kesadaran diri. Perempuan berjilbab mensyaratkan "hati" yang telah terjilbabi terlebih dahulu. Artinya berjilbab harus secara kaffah, tidak setengah-setengah apalagi hanya untuk memenuhi tuntutan mode atau mendatangkan keuntungan dalam penampilan fisik. Secara psikologis, Rifka menganggap dirinya belum pantas berjilbab karena syarat-syarat menjadi perempuan berjilbab belum terpenuhi.

Dalam pandangannya tersebut Rifka mensakralkan arti jilbab sebagai simbol dari ketaatan beragama. Hal ini yang menjadikannya tidak setuju 
dan tidak menoleransi perempuan-perempuan yang berjilbab, tetapi masih memakai pakaian ketat atau berjilbab tapi tetap memperlihatkan bagian tubuh yang seharusnya ditutup. Jadi, daripada berjilbab tidak kaffah antara penampilan dan hati serta tidak sesuai dengan syariat, lebih baik jangan berjilbab dahulu, demikian pandangan Rifka.

\section{Pengalaman Rini}

Rini berasal dari Gresik. Sekolah menengah atas-nya dahulu memberlakukan aturan berjilbab bagi siswa perempuan. Untuk itu, Rini selalu berjilbab ketika bersekolah kendati di rumah atau di luar lingkungan sekolah lebih sering tidak memakai jilbab. Alasan tetap tidak berjilbab karena estetika penampilan.

Rini mengaku tidak mempermasalahkan sistem pembelajaran dan tata tertib di BEC. Mengenai aturan berjilbab dan aturan-aturan yang lain, telah Rini ketahui semenjak awal. Hal yang ditakutkan Rini jika sampai melanggar adalah dikenai sanksi dan hukuman. Sepengetahuannya jika melakukan pelanggaran, bisa tidak naik kelas dan terkena hukuman. Salah satu bentuk hukuman adalah unsuccess, yakni lulus tetapi tidak mendapat sertifikat. Jika sampai mendapatkan hukuman unsuccess, menurut Rini sangat disayangkan, karena seakan percuma telah belajar selama tiga bulan tanpa mendapatkan sertifikat.

Menurut Rini, berjilbab adalah kewajiban bagi perempuan Muslim, tetapi banyak juga perempuan yang tidak berjilbab. Itu artinya kewajiban jilbab mungkin tidak sewajib ibadah lain seperti shalat atau puasa. Lagipula perintah berjilbab dalam agama berhubungan dengan masalah keamanan dan perlindungan seorang perempuan. Jadi, manakala kondisi telah aman dan terlindungi, perempuan tidak terlalu diwajibkan untuk berjilbab.

Dalam berjilbab, Rini lebih bertumpu pada aspek pragmatis sesuai dengan manfaat yang diperoleh untuk memperbaiki penampilan. Dengan demikian, Rini menerima praktik jilbab atas dasar motif modis. Pada pemakaiannya tidak konsisten dan pragmatis, Rini menganggap jilbab lebih kepada pilihan berpakaian daripada simbol agama. Rini tidak mengaitkan jilbab dengan motif psikologis dan teologis seperti pengendalian diri dari perbuatan dosa, sarana mencapai ketenangan hati, atau lainnya. 


\section{Pengalaman Nabila}

Nabila mulai berjilbab sejak kelas 2 SMP. Ketika menempuh pendidikan di SMA, Nabila bergabung dengan organisasi keagamaan tingkat sekolah. Selanjutnya, ia mulai mengikuti kajian-kajian "garis keras" yang membuatnya terdorong untuk semakin memperlebar jilbab yang dikenakan dan tidak pernah memakai bawahan model celana. Setelah lulus SMA, Nabila melanjutkan studi ke universitas swasta di Surabaya. Di sekolah yang baru, ia merasa menjadi orang yang "aneh" karena penampilannya sangat berbeda dengan mahasiswamahasiswa lain. Pada sekitar semester kedua, Nabila mulai sedikit demi sedikit mengubah penampilan: menanggalkan jilbab lebar dan sering menggunakan celana kain.

Perubahan yang dialaminya dilatarbelakangi faktor internal dan eksternal. Faktor internal datang dari diri sendiri karena merasa tidak nyaman dengan kondisinya di tengah-tengah lingkungan pergaulannya. Di sisi lain, faktor eksternal datang dari orangtua atau ibunya. Nabila menceritakan pengalamannya bahwa dahulu ia sering diperingatkan sang ibu bahwa dengan berpenampilan sebagaimana ia dahulu, besar kemungkinan bisa dipoligami oleh suaminya kelak. Pada saat itu, media massa sedang hangat mengangkat pemberitaan poligami yang dilakukan tokoh masyarakat Abdulah Gymnastiar (AA Gym).

Pada term tentang jilbab, Nabila berkeyakinan bahwa jilbab merupakan kewajiban bagi perempuan Muslim. Ia tidak setuju dengan konsep bahwa ketika perempuan akan berjilbab harus terlebih dahulu memperbaiki diri. Ini karena menurutnya, ketika perempuan mau berjilbab, maka hatinya akan turut terjilbabi. Dalam hal ini, Nabila menghubungkan jilbab dalam motif psikologis dan teologis. Ia memandang jilbab sebagai sarana pengaman, baik dalam hubungan vertikal dengan Tuhan, maupun horizontal dengan sesama manusia.

Nabila menganggap berjilbab yang mensyaratkan kondisi-kondisi tertentu merupakan manfaat dari berjilbab. Dalam motif dan aspek teologis, jilbab sebagai perintah agama dan manifestasi ketakwaan menjadikan si pemakai berupaya mengendalikan diri dari hal-hal yang dilarang agama. Dengan demikian, berbeda dengan pandangan Rifka yang mensyaratkan 
iman dan takwa sebelum berjilbab, Nabila menganggap jilbab sebagai sarana untuk memperoleh iman dan ketakwaan itu sendiri.

\section{Pengalaman Titin}

Dalam keseharian, Titin tidak mengenakan jilbab. Bahkan sejak kecil hingga dewasa ia hanya berjilbab saat hari-hari raya dengan model selendang yang disampirkan di kepala. Jadi, berjilbab di BEC merupakan pengalaman baru yang mana ia harus benar-benar mengenakan jilbab. Ini menurut Titin menjadi kesulitan tersendiri karena ia harus berdandan lebih lama untuk dapat mengenakan jilbab dengan baik dan pantas.

Selain faktor ketidakbiasaan, Titin menganggap jilbab bukan sekadar pakaian, melainkan simbol yang mencerminkan hati si pemakai. Jadi, perempuan mau berjilbab atau tidak adalah keputusan pribadi yang seharusnya tidak diatur dan dipaksa. Kondisinya yang tidak berjilbab kemudian harus berjilbab saat belajar di BEC merupakan sesuatu yang dianggap oleh Titin sebagai beban. Ia yang awalnya ingin belajar bahasa Inggris setelah masuk BEC malah merasa tidak fokus belajar karena terlalu memikirkan masalah baju, jilbab, dan aturan-aturan.

Jilbab dimaknai oleh Titin sebagai hal yang bersifat pribadi dan privat yang tidak seharusnya dicampuri oleh pihak luar. Pandangan Titin hampir senada dengan pandangan Rifka, yakni sebelum perempuan mengenakan jilbab harus terpenuhi syarat ketakwaan. Titin merasa belum siap berjilbab karena merasa belum memenuhi syarat ketakwaan. Jilbab selain beraspek teologis juga mencakup motif psikologis. Dalam pandangannya, berjilbab mensyaratkan kondisi psikologi yang ikhlas sehingga mampu dan siap menanggung konsekuensi-konsekuensi yang mesti ditanggung dari keberadaan jilbab yang dipakai.

\section{Keberagaman Konstruksi Makna Jilbab}

Keempat subjek menceritakan pengalaman berjilbab saat mengikuti aturan berjilbab di lembaga kursus BEC. Rifka mewakili para peserta yang tidak setuju dengan aturan berjilbab, tetapi masih mengikuti aturan. Rini mewakili para peserta yang menaati peraturan, tetapi dilandasi kepentingan 
tertentu, yakni belajar bahasa Inggris. Nabila mewakili para peserta yang setuju dan mendukung aturan berjilbab. Titin mewakili peserta yang tidak setuju dan melakukan penolakan dengan berpindah ke tempat kursus lain.

Keberagaman tanggapan dari peserta kursus terhadap aturan berjilbab mengindikasikan bahwa para peserta merupakan subjek-subjek aktif. Keaktifan subjek memberikan peluang bagi resistensi. Figur Kalend memang mampu melakukan dominasi dalam arena sosial lembaga BEC. Namun, para peserta kursus sebagai pihak yang didominasi tetap memiliki kebebasan dalam bertindak sehingga memunculkan tindakan apakah setuju dan taat ataukah tidak setuju dan memilih menolak.

Dari narasi pengalaman keempat subjek dapat dipetakan tiga macam bentuk tanggapan terhadap aturan berjilbab, yakni 1) setuju; 2) tidak setuju; 3) taat dengan catatan atau kepentingan tertentu. Tiga bentuk tanggapan tersebut menghasilkan tiga bentuk penerimaan diri terhadap term jilbab. Bentuk penerimaan merupakan praktik yang dilakukan oleh individu sebagai hasil dari habitus yang dibentuk dari pengalaman masa lalu, latar belakang keluarga, pola pendidikan yang diterima, dan kebiasaan sehari-hari. Narasi dari pengalaman subjek yang dijelaskan pada subbab sebelumnya secara tidak langsung menguraikan tentang unsur-unsur pembentuk habitus mereka.

Dengan demikian, bentuk tanggapan, entah setuju, tidak setuju, atau taat atas dasar kepentingan, bermuara dari habitus seseorang. Adanya beberapa kesamaan antara habitus Kalend dan Nabila menjadikan keduanya memiliki pandangan yang kurang lebih serupa sehingga memunculkan respons setuju. Sementara subjek lain memiliki habitus yang cenderung berbeda sehingga menampilkan respons kedua dan ketiga. Namun, penjelasan tersebut belum menjangkau pada persoalan bagaimana aturan tersebut mapan diterapkan kendati dengan respons yang beragam. Mengapa respons tidak setuju yang diwakili subjek Rifka dan respons taat karena kepentingan tertentu yang diwakili Rini pada kenyataan mau berjilbab?

Untuk menjawab pertanyaan tersebut, kekuasaan dan dominasi Kalend tidak dipahami sebagai kekuasaan yang bersifat tradisional. Mengikuti pandangan Michel Foucault, kekuasaan bukan sesuatu yang dimiliki yang dapat diperoleh, dipegang, atau diperebutkan, melainkan dipraktikkan 
dalam suatu ruang lingkup di mana ada banyak posisi strategis berkaitan satu dengan yang lain. Kekuasaan bukan sesuatu yang datang dari luar, melainkan menentukan susunan, aturan, dan hubungan dari dalam. Manuver kekuasaan bukan terletak pada bagaimana memaksa seseorang untuk patuh, melainkan melalui cara regulasi dan normalisasi. Implikasinya, kekuasaan bukan menjadi sesuatu yang mengancam atau menakutkan, melainkan sesuatu yang familiar ${ }^{10}$.

Foucault memandang kekuasaan tidak diproduksi dan direproduksi berdasarkan hubungan kepemilikan. Kuasa justru berlangsung di mana-mana, yakni di mana manusia mempunyai hubungan tertentu satu sama lain dan dengan dunia, maka di situ kuasa bekerja. Kuasa menentukan hubungan, susunan, dan aturan-aturan dari dalam yang bekerja melalui normalisasi dan regulasi. Kuasa terutama berkaitan dengan pengetahuan sebab tidak ada pengetahuan tanpa kuasa dan sebaliknya tidak ada kuasa tanpa pengetahuan ${ }^{11}$.

\section{E. Tubuh dan Kekuasaan dalam Bingkai Konstruksi Wacana Berjilbab}

Metode untuk mengetahui mengapa dan bagaimana para peserta perempuan taat berjilbab, yakni dengan menelusuri saluran-saluran penyebarluasan kekuasaan melalui beragam wacana yang dikonstruksi. Dalam aturan dan praktik berjilbab, wacana yang terbentuk ialah perempuan yang berjilbab adalah perempuan yang bermoral baik. Hal ini sebagaimana terepresentasi pada pandangan Nabila bahwa perempuan Muslim memang seharusnya berjilbab. Kuatnya wacana ini menjadikan para peserta yang enggan berjilbab seperti Titin akan malu ketika dipergoki tidak berjilbab.

Ketika masih menjadi peserta di BEC, Titin menceritakan bahwa ia malu kepada sesama teman ketika ketahuan tidak berjilbab. Pun begitu dengan subjek Rini yang sangat berhati-hati dan memperhitungkan keadaan apabila ia sedang tidak berjilbab. Dengan demikian, seakan-akan perempuan yang tidak berjilbab adalah keadaan yang tidak normal sehingga mereka harus menanggung malu. Di sinilah terdapat proses normalisasi bahwa yang normal adalah yang berjilbab, sedangkan tidak berjilbab adalah tidak normal. Wacana

\footnotetext{
10 Michel Foucault, Disipline and Punish: The Birth of the Prison. Terj. Alan Sheridan,(New York: Vintage Books, 1995).

11 K. Bertens, Filsafat Barat Modern Prancis,(Jakarta: Gramedia Pustaka Utama, 2007), hlm. 354-357.
} 
ini tidak diciptakan Kalend, tetapi tersebar dan dipercayai oleh warga BEC bahkan sekalipun tidak ada Kalend di puncak pimpinan. Sebab, seperti diceritakan Titin bahwa dia malu bertemu temannya bahkan di luar area BEC (di luar area kepemimpinan Kalend) mengindikasikan bahwa wacana tersebut tersebar di antara para warga. Para warga saling mengawasi dan menilai para perempuan di antara mereka apakah memakai jilbab atau tidak.

Wacana lain yang dikonstruksi adalah jika ingin pintar maka berjilbab atau menjadi pintar dengan berjilbab. Wacana ini melandasi pembentukan aturan berjilbab, yakni praktik mengenakan jilbab menjadi tolok ukur kesiapan seseorang menerima pelajaran. Syarat untuk mengikuti pelajaran dan lulus dari BEC adalah perempuan diharuskan berjilbab. Tanpa berjilbab seakan siswi tidak pantas untuk lulus dari pelajaran bahasa Inggris. Maka, jilbab yang merupakan jenis atau mode berpakaian dihubungkan dengan aspek kepintaran.

Wacana ini memengaruhi para perempuan untuk menuruti aturan berjilbab, seperti yang terjadi pada Rini dan Rifka. Rini dalam keseharian tidak berjilbab, tetapi mau berjilbab karena ingin belajar di BEC. Dilihat dari habitus dan motif Rini berjilbab, tidak sesuai dengan tujuan atau pandangan Kalend menetapkan aturan. Akan tetapi, di sini wacana bekerja memengaruhi Rini, yakni "jika ingin pintar, berjilbablah.” Proses yang sama pun terjadi pada Rifka yang sebenarnya tidak menyetujui aturan berjilbab. Bahkan, baginya berjilbab membuatnya merasa tidak nyaman. Meskipun demikian, ia tetap berupaya berjilbab karena menjadi bagian dari proses menguasai bahasa Inggris.

Selain itu, dimaknai pula bahwa tekanan para peserta BEC untuk berjilbab tidak melulu berasal dari aturan, tetapi juga bangkit dari internal individu. Hampir semua subjek, baik Rifka, Nabila, maupun Titin menyadari kepentingan berjilbab. Dalam tataran ini terjadi proses normalisasi dan regulasi wacana jilbab yang mendapatkan legitimasi dari ajaran agama Islam. Norma dan aturan agama memerintahkan agar perempuan menutup tubuh dengan cara berpakaian jilbab. Pengetahuan ini menjadi landasan yang menopang wacana-wacana di atasnya. Maka, sebagaimana dalam pemikiran Foucault bahwa pengetahuan akan melahirkan kekuasaan, di sini pun demikian. Pengetahuan tentang norma dan aturan agama mampu mengatur tubuhtubuh individu sesuai yang diharapkan. 
Wacana-wacana tentang jilbab tersebar, dibangkitkan, dan dibagikan di antara para warga. Para guru bercerita tentang pentingnya menaati aturan berjilbab dan risiko apa yang harus ditanggung jika melanggar. Pun begitu dalam pergaulan antar-peserta, mereka saling memberi tahu risiko-risiko tersebut. Bahkan, cerita yang disebarkan entah benar-benar terjadi entah tidak, tetapi dipercayai oleh para peserta. Contohnya adalah subjek Rini. Ia mendengar cerita tentang akibat melanggar aturan, yakni unsuccess. Akan tetapi, ia sebenarnya tidak benar-benar memahami predikat unsuccess dan bagaimana sanksi tersebut diterapkan. Ia secara pribadi tidak pernah memiliki pengalaman, baik melihat atau mengalami teguran atau sanksi pelanggaran.

Hal lain yang patut diperhatikan adalah nametag yang wajib dipakai oleh peserta saat jam-jam belajar di lingkungan BEC. Nametag menginformasikan nama dan kelas berfungsi sebagai tanda pengenal. Dengan adanya nametag, para guru akan lebih mudah mengenali siswa, baik di dalam maupun di luar kelas. Kemudahan mengenal akan memudahkan proses pengawasan: apakah siswa melakukan pelanggaran atau tidak. Namun, pengawasan tersebut tidak hanya bekerja secara eksternal guru mengawasi murid, tetapi juga pengawasan secara internal. Keberadaan nametag yang menginformasikan siapa mereka disadari oleh peserta bahwa mereka akan mudah dikenali jika melanggar.

Fungsi pengawasan dari nametag hampir mirip dengan fungsi panoptikon, di luar aspek interiorisasi, yang melakukan pengawasan terhadap diri individu. Michel Foucault ${ }^{12}$ mengatakan bahwa mekanisme panoptikon mengaturdan mengindividualisasikan subjek-subjek menjadi lebih mudah dikenali dandiamati secara konstan. Pengawasan macam panoptikon adalah pengawasan yang memeriksa, yang mana setiap individu membawa pengawasan tersebut ke dalam dirinya sendiri ${ }^{13}$.

Maka, persoalan kepatuhan para peserta mengikuti aturan tidak hanya dilatarbelakangi oleh wacana-wacana yang berstrategi membentuk dan dibentuk oleh pengetahuan bahwa yang normal adalah yang berjilbab, tetapi juga karena pengawas berada di mana-mana. Pengawas ada di dalam diri dan ada di luar diri. Pengawas mudah mengenali karena para peserta terindividualiasi menurut nama-nama diri sehingga tidak memungkinkan mampu sembunyi dibalik kolektivitas para peserta yang berjumlah banyak.

12 Michel Foucault, Disipline and..., hlm. 200.

13 Michel Foucault, Ibid. hlm. 192. 
Selain nametag, jilbab pun dapat berfungsi sebagai pengawas untuk si pemakai. Hal ini diungkapkan oleh Nabila bahwa berjilbab akan memberikan kerangkeng mengenai tindakan yang pantas dan tidak pantas dilakukan, baik dalam hubungan vertikal maupun horizontal. Aspek pengawasan berkaitan dengan wacana perempuan yang berjilbab adalah bermoral baik. Jadi, perempuan-perempuan peserta BEC berada pada silang sengkurat pengawasan dan pewacanaan bahwa mereka harus berjilbab. Keharusan tersebut meminimalisasi atau bahkan meniadakan kebebasan individu bahwa berpenampilan adalah ekspresi diri. Bentuk-bentuk kebebasan ekspresi yang dapat ditampilkan dari cara berpakaian tidak dapat dengan mudah dilakukan dalam ranah BEC karena ada sejumlah wacana yang mengarahkan individu memilih cara berpakaian tertentu.

Dari uraian di atas, dicermati bahwa tubuh-tubuh milik individu dikontrol dalam jejaring wacana dalam ruang sosial. Otoritas individu sebagai si pemilik tubuh larut dalam disiplin penormalisasian karena mereka takut dicap sebagai abnormal. Pada dasarnya, BEC sebagai suatu miniatur ranah sosial mencerminkan upaya-upaya di mana tanda-tanda patologi sosial nondisiplin berusaha dikontrol dengan teliti. Dengan model pendisiplinan dan menjadikan jilbab sebagai media pengawasan diri pribadi, BEC hendak meminimalisasi perilaku atau individu yang dipandang abnormal. Konsep tentang normal-abnormal diregulasi dalam wacana ajaran agama Islam, yang memandang perempuan yang baik adalah perempuan yang berjilbab; manusia yang baik adalah yang patuh dan taat.

Proses pengawasan yang tersebar di mana-mana berimplikasi pada tertanamnya kesadaran pada diri individu bahwa diri mereka (para peserta kursus) visibel. Dalam visibilitas, mereka sadar bahwa setiap saat diawasi sehingga mau tidak mau berlaku normal dan mematuhi disiplin. Dalam pandangan Foucault, jika individu sadar untuk berlaku normal dan mematuhi disiplin, artinya individu tersebut telah terperangkap dalam situasi kekuasaan, yang kemudian justru menjadi pelaku yang mendukung relasi kekuasaan itu sendiri. Pada kondisi demikian, relasi pengawasan akan berjalan secara mandiri dan otomatis. Mereka akan mengawasi diri mereka sendiri untuk patuh dan disiplin. 
Foucault menulis bahwa menara pengawas dalam panoptisme selain dioperasikan oleh petugas, juga dapat digunakan oleh banyak individu dengan berbagai kepentingan. Maka, dalam konteks BEC, konsep pengawasan dan visibilitas individu merupakan kepentingan untuk membentuk kesadaran beragama. Ini karena pengawasan dan kesadaran diawasi adalah hal penting dalam kesadaran beragama. Seseorang agar patuh terhadap ajaran agama yang diyakini harus mengembangkan kesadaran diri bahwa ia diawasi. Ada penilaian terhadap segala tingkah lakunya, entah tingkah laku tersebut dilihat oleh orang lain entah tidak, bahkan entah sebatas dalam pikiran. Maka dari itu, menjadi orang beragama adalah menjadi orang yang visibel. Dengan menjadi orang beragama, kehendak bebas dan hak keindividuan sudah tidak lagi prinsip.

\section{F. KESIMPULAN}

Aturan berjilbab seperti yang telah didedah dalam tulisan ini merupakan politik tubuh. Jilbab menjadi media efektif untuk mengendalikan ruang privat individu yang punya kepentingan untuk melakukan kontrol dan penetrasi. Di sini kekuasaan berupaya membentuk dan mengelola individualitas yang diinginkan. Jilbab membatasi kemungkinan alternatif lain dari sebuah tubuh perempuan. Namun mengapa tubuh perempuan? Jika ranah sosial BEC dilepaskan dari fakta bahwa ia adalah tempat kursus dan diandaikan sebagai miniatur masyarakat, akan terlihat sesuatu yang berbeda. Kontrol atas tubuh perempuan dalam suatu masyarakat adalah upaya mengendalikan dorongan seksualitas.

Tubuh perempuan memiliki daya tarik seksual bagi para laki-laki yang melihatnya. Maka, cara untuk mengendalikan dorongan seksual adalah dengan cara mengatur tubuh perempuan. Tubuh perempuan yang tertutup adalah yang diinginkan karena tidak terlihat oleh mata-mata laki-laki yang melihat. Dengan demikian, untuk menghasilkan masyarakat yang teratur ialah dengan cara mengatur tubuh perempuan. Dalam tataran ini jilbab menjadi media efektif dalam fungsinya sebagai panoptikon individu. 


\section{DAFTAR PUSTAKA}

Barnad, Malcolm. 2011. Fashion sebagai Komunikasi. Terj. Idi Subandi Ibrahim. Yogyakarta: Jalasutra.

Bertens, K. 2007. Filsafat Barat Modern Prancis. Jakarta: Gramedia Pustaka Utama.

Bourdieu, Pierre. 1995. Outline of a Theory of Practice. New York: Cambridge University Press.

Brenner, Suzzane. "Reconstructing Self and Society: Javanese Muslim Women and 'The Veil'". Dalam American Ethnologist, Vol. 23, No. 4 (November 1996).

El-Guidi, Fadwa. 1999. Veil, Modesty, Privacy, and Resistance. Oxford. New York: Berg.

Fauzi, Moh. 2008. Formalisasi Syariat Islam di Indonesia. Semarang: Walisongo Press.

Foucault, Michel. 1995. Disipline and Punish: The Birth of the Prison. Terj. Alan Sheridan. New York: Vintage Books.

Matthewman, Adelen. “Jilbabisasi Mengapa Muslimah Jawa Berjilbab.” Tugas Studi Lapangan. Malang: ACICIS bekerja sama dengan Universitas Muhammadiyah Malang.

Nordholt, Henk Schulte (ed.) 2005. Outward Appearances: Tren, Identitas, Kepentingan. Terj. M. Imam Aziz. Yogyakarta: LKiS.

Suyono, Joko Seno. 2002. Tubuh yang Rasis, Telaah Kritis Michel Foucault Atas Dasar-Dasar Pembentukan Diri Kelas Menengah Eropa. Yogyakarta: Pustaka Pelajar.

Syamsudini, M. "Kasus Jilbab di Sekolah-Sekolah Negeri." Dalam http:// mydetik.blogspot.com/2011/06/kasus-jilbab-di-sekolah-sekolahnegeri. html. Diakses pada 23 Oktober 2013.

Umar, Nasrudin. “Antropologi Jilbab.” Dalam Ulumul Quran No. 5 Vo. VI Tahun 1996. 